\title{
Distribution and Analysis of Heavy Metals Contamination in Soil, Perlis, Malaysia
}

\author{
Ain Nihla Kamarudzaman ${ }^{1, *}$, Yee Shan Woo ${ }^{1}$, and Mohd Faizal Ab Jalil ${ }^{2}$ \\ ${ }^{1}$ School of Environmental Engineering, Universiti Malaysia Perlis, Kompleks Pusat Pengajian Jejawi \\ 3, 02600 Arau, Perlis, Malaysia \\ ${ }^{2}$ Perlis State Department of Environment, $2^{\text {nd }}$ Floor, KWSP Building, Jalan Bukit Lagi, 01000 \\ Kangar, Perlis, Malaysia
}

\begin{abstract}
The concentration of six heavy metals such as $\mathrm{Cu}, \mathrm{Cr}, \mathrm{Ni}, \mathrm{Cd}$, $\mathrm{Zn}$ and $\mathrm{Mn}$ were studied in the soils around Perlis. The aim of the study is to assess the heavy metals contamination distribution due to industrialisation and agricultural activities. Soil samples were collected at depth of $0-15 \mathrm{~cm}$ in five stations around Perlis. The soil samples are subjected to soil extraction and the concentration of heavy metals was determined via ICP - OES. Overall concentrations of $\mathrm{Cr}, \mathrm{Cu}, \mathrm{Zn}, \mathrm{Ni}, \mathrm{Cd}$ and $\mathrm{Mn}$ in the soil samples ranged from $0.003-0.235 \mathrm{mg} / \mathrm{L}, 0.08-41.187$ $\mathrm{mg} / \mathrm{L}, 0.065-45.395 \mathrm{mg} / \mathrm{L}, 0.031-2.198 \mathrm{mg} / \mathrm{L}, 0.01-0.174 \mathrm{mg} / \mathrm{L}$ and $0.165-63.789 \mathrm{mg} / \mathrm{L}$ respectively. The concentration of heavy metals in the soil showed the following decreasing trend, $\mathrm{Mn}>\mathrm{Zn}>\mathrm{Cu}>\mathrm{Ni}>\mathrm{Cr}>\mathrm{Cd}$. From the result, the level of heavy metals in the soil near centralised Chuping industrial areas gives maximum value compared to other locations in Perlis. As a conclusion, increasing anthropogenic activities have influenced the environment, especially in increasing the pollution loading.
\end{abstract}

\section{Introduction}

Soil is very important fundamental of natural resource for human survival [1]. Plot of land is important for recycling and redistribution of nutritious elements. Heavy elements and trace elements in the ground system is increasingly becoming a global concern, mainly because the soil is an important component of urban and rural areas [2]. In general, heavy metals deposition on the soil surface is due to natural formation on earth and also human activities such as industrialisation and agricultural activities. Heavy metals can be accumulated in topsoil through atmospheric deposition by sedimentation, impaction and interception [3]. Although some of the trace elements are important in the soil, however, the concentration of heavy metals in the soil at high quantities can be harmful to the environment [2].

In recent years, the heavy metals contamination in soil is a serious threat to the environment, ecosystems and human health. The atmospheric dust and aerosol deposition, automobile exhaust emissions, and various industrial activities are important sources of

* Corresponding author: ainnihla@unimap.edu.my 
heavy metals contamination of soil [2]. Increasing anthropography activities will influences on the environment, particularly the burden of pollution, adverse changes in natural ecosystems and biodiversity decline. Besides, heavy metals pollution in agricultural soils also increased due to reuse of untreated industrial wastewater and the use of fertilizers and pesticides in agriculture activities [4]. As a result, excessive accumulation of heavy metals through agriculture activities can cause pollution not only to the soil but also to the quality and safety of the food. The dangerous possibility may occur such as contamination of the crop and influence the plant growth.

Heavy metals pollution in soil can cause harm and damage to the human and ecology through the digestive directly or contact with contaminated soil, food chain, drinking groundwater contaminated, increasing the problem of land and land use rights in agricultural production leading to food security [5]. Many studies have shown that exposure to toxic contaminants is influenced by a variety of factors, including exposure, absorption, metabolism and distribution in the human body [2]. Therefore, the objective of the study is to assess the heavy metals contamination distribution in the soil due to industrialisation and agricultural activities.

\section{Methodology}

\subsection{Study Area}

Perlis is located northern part of the west coast of Peninsular Malaysia $\left(6^{\circ} 30^{\prime} \mathrm{N}, 100^{\circ}\right.$ $\left.15^{\prime} \mathrm{E}\right)$. This area undergoes various anthropogenic activities such as cement, chemical, quarry, power plant, transportation and agriculture activities that might contribute to heavy metals contamination. Soil samples were collected at 5 stations around Perlis such as Jejawi, Kangar, Chuping, Kuala Perlis and Beseri. Soil samples at depth $0-15 \mathrm{~cm}$ were collected using hand auger and stored in plastic bag. All soil samples were properly labelled before transported to the laboratory. Global Positioning System (GPS) records the coordination of sampling points. Table 1 show the location coordinates for soil sampling in Perlis.

Table 1. Location of sampling point.

\begin{tabular}{|c|c|c|}
\hline Location & Latitude (N) & Longitude (E) \\
\hline Jejawi & 6.26 .265 & 100.13 .420 \\
\hline Chuping & 6.30 .465 & 100.19 .097 \\
\hline Kangar & 6.26 .262 & 100.11 .541 \\
\hline Kuala Perlis & 6.24 .210 & 100.09 .169 \\
\hline Beseri & 6.32 .320 & 100.18 .519 \\
\hline
\end{tabular}

\subsection{Soil Preparation}

After sampling, the grass and unwanted materials were removed from the soil samples and the soil samples were stored in polyethylene bottles. The soil samples were dried in an oven at $105^{\circ} \mathrm{C}$ for 2 days. After drying, the soil samples were crushed using mortar and pestle. Subsequently, the soil samples were sieved through a $2 \mathrm{~mm}$ sieve and stored in polyethylene bottles under room temperature. 


\subsection{Analytical Method}

In order to identify the elemental composition in the soil samples, the X-ray fluorescence (XRF) test was conducted. Prior to the XRF analysis, the soil samples were oven dried at $105^{\circ} \mathrm{C}$ overnight, grinded and sieved to obtain soil samples size of less than $75 \mu \mathrm{m}$ and pressed into pallet by using hydraulic Pellet Press model PP 25. Meanwhile, in order to assess the concentration of heavy metals in the soil samples, the Inductively Coupled Plasma Optical Emission Spectrometry (ICP - OES) was conducted. The soil extraction was carried out using EDTA method. $0.05 \mathrm{~mol}$ of EDTA solution was prepared by dissolving $14.61 \mathrm{~g}$ of EDTA powder into $1 \mathrm{~L}$ of distilled water. The mixture was stirred until fully dissolved. Next, about $5 \mathrm{~g}$ of soil sample was mixed with $20 \mathrm{ml}$ of 0.05 mol of EDTA solution and shaken at $100 \mathrm{rpm}$ for 60 minutes on a rotary shaker. The extraction solution was filtered through Whatman No. 42 paper. All heavy metals analysis performed by Inductively Coupled Plasma Optical Emission Spectrometry (ICP - OES).

\section{Results and discussions}

\subsection{Elemental Composition in Soil}

The elemental composition analysis in the soil samples using XRF includes major and minor elements such as $\mathrm{S}, \mathrm{Si}, \mathrm{Ca}, \mathrm{Fe}, \mathrm{K}$ (major) and $\mathrm{Cd}, \mathrm{Ti}, \mathrm{V}, \mathrm{Mn}, \mathrm{Cr}, \mathrm{Cu}, \mathrm{Ni}$, $\mathrm{Pb}, \mathrm{Sr}$, and $\mathrm{Zn}$ (minor). Table 2 and Table 3 showed that the elemental composition of the soils collected from five locations in Perlis. From Table 2, the percentages of $\mathrm{Si}, \mathrm{Ca}, \mathrm{Fe}$ and $\mathrm{Al}$ were higher than other elements. The percentage of calcium was the highest (4-89\%) in the XRF result. The highest percentage of calcium due to the soil is collected nearby to the cement factory at Beseri. In addition, the XRF result also shows that the percentage of $\mathrm{Si}$ is around $18-59 \%$ in Perlis, which is the second higher compared with other elements in the soil samples. $\mathrm{Si}$ is the second most abundant element in the crust of the earth after oxygen [6].

Table 2. Major element compositions in the soil samples.

\begin{tabular}{|c|c|c|c|c|c|}
\hline \multirow{2}{*}{ Element } & \multicolumn{5}{|c|}{ Percentage of elements at five location in unit \% } \\
\cline { 2 - 6 } & Beseri & Chuping & Jejawi & Kangar & $\begin{array}{c}\text { Kuala } \\
\text { Perlis }\end{array}$ \\
\hline $\mathrm{S}$ & - & 0.93 & 0.44 & 0.14 & 0.48 \\
\hline $\mathrm{Si}$ & 3.67 & 54.2 & 33.6 & 58.9 & 18.1 \\
\hline $\mathrm{Ca}$ & 89.07 & 17.3 & 30.8 & 4.35 & 63.65 \\
\hline $\mathrm{Fe}$ & 3.41 & 14.1 & 16.07 & 15.22 & 7.85 \\
\hline $\mathrm{K}$ & - & 2.11 & 4.18 & 3.25 & 2.92 \\
\hline $\mathrm{Al}$ & 2.80 & 7.39 & 12.10 & 13.60 & 5.29 \\
\hline
\end{tabular}

\subsection{Distribution of Heavy metals}

Five different location of soils were analysed by ICP- OES for six elements which are Cr, $\mathrm{Cu}, \mathrm{Zn}, \mathrm{Ni}, \mathrm{Cd}$ and $\mathrm{Mn}$. The concentrations of each heavy metals are shown in Table 4. Obviously, the concentration of $\mathrm{Mn}$ in soil was detected at highest concentration in all location. The highest $\mathrm{Mn}$ concentration in soil, which is $63.79 \mathrm{mg} / \mathrm{L}$ was found at the centre of Chuping. On the other hand, the maximum concentration of $\mathrm{Ni}, \mathrm{Zn}$ and $\mathrm{Cu}$ in the soil 
samples are $2.198 \mathrm{mg} / \mathrm{L}, 45.39 \mathrm{mg} / \mathrm{L}$ and $41.187 \mathrm{mg} / \mathrm{L}$ respectively. These heavy metals were also detected at the same location in Chuping.

Table 3. Minor element compositions in the soil samples.

\begin{tabular}{|c|c|c|c|c|c|}
\hline \multirow{2}{*}{ Element } & \multicolumn{5}{|c|}{ Percentage of elements at five location in unit \% } \\
\cline { 2 - 6 } & Beseri & Chuping & Jejawi & Kangar & $\begin{array}{c}\text { Kuala } \\
\text { Perlis }\end{array}$ \\
\hline $\mathrm{Ti}$ & 2.80 & 7.39 & 12.1 & 13.60 & 5.29 \\
\hline $\mathrm{V}$ & 0.03 & 0.03 & 0.06 & 0.05 & 0.03 \\
\hline $\mathrm{Cr}$ & 0.02 & 0.05 & 0.04 & 0.05 & 0.03 \\
\hline $\mathrm{Mn}$ & 0.20 & 0.16 & 0.20 & 0.38 & 0.24 \\
\hline $\mathrm{Cu}$ & 0.06 & 0.17 & 0.11 & 0.11 & 0.09 \\
\hline $\mathrm{Zn}$ & 0.04 & 0.10 & 0.16 & 0.05 & 0.04 \\
\hline
\end{tabular}

Table 4. The concentration of heavy metals by ICP - OES.

\begin{tabular}{|c|c|c|c|c|c|}
\hline \multirow{2}{*}{ Element } & \multicolumn{5}{|c|}{ Concentration of heavy metals at five location in mg/L } \\
\cline { 2 - 6 } & Beseri & Chuping & Jejawi & Kangar & Kuala Perlis \\
\hline $\mathrm{Cr}$ & 0.147 & 0.235 & 0.056 & 0.004 & 0.003 \\
\hline $\mathrm{Cu}$ & 0.404 & 41.187 & 7.412 & 0.086 & 0.080 \\
\hline $\mathrm{Zn}$ & 24.077 & 45.390 & 24.439 & 0.140 & 0.065 \\
\hline $\mathrm{Ni}$ & 0.116 & 2.198 & 0.26 & 0.031 & 1.840 \\
\hline $\mathrm{Cd}$ & 0.098 & 0.174 & 0.010 & 0.047 & 0.048 \\
\hline $\mathrm{Mn}$ & 32.159 & 63.789 & 37.00 & 0.165 & 2.823 \\
\hline
\end{tabular}

The result showed that all six elements such as $\mathrm{Cu}, \mathrm{Cr}, \mathrm{Ni}, \mathrm{Cd}, \mathrm{Zn}$ and $\mathrm{Mn}$ were highly distributed in Chuping. The sampling location for this soil was located near the Chuping industrial area and near to the main road, which loads with heavy traffic. Such industrial activities include cement production, chemical plant processing, quarry, and sugar plant have operated in the Chuping industrial area. Therefore, these industrial activities indirectly contributed to the heavy metal pollution in the soil. A study by [7] reported that $\mathrm{Cu}, \mathrm{Zn}$ and $\mathrm{Cr}$ mainly derived from industrial activities and traffic emissions. Heavy vehicles also give large contribution in depositing of $\mathrm{Cu}, \mathrm{Cr}$ and $\mathrm{Ni}$ in soil through traffic emission.

\subsection{Descriptive Statistics}

Table 5 presents the descriptive statistics of the heavy metals concentration such as mean, standard deviation, maximum and minimum for soils of Perlis state. The mean values of each heavy metals concentration in soils showed that the values were below the guidelines limit as shown in Table 6 . The total mean concentrations of heavy metals in five different locations are $\mathrm{Cr}(0.089 \mathrm{mg} / \mathrm{L}), \mathrm{Cu}(9.834 \mathrm{mg} / \mathrm{L}), \mathrm{Zn}(18.822 \mathrm{mg} / \mathrm{L}), \mathrm{Ni}(0.889 \mathrm{mg} / \mathrm{L}), \mathrm{Cd}$ $(0.075 \mathrm{mg} / \mathrm{L})$ and $\mathrm{Mn}(27.187 \mathrm{mg} / \mathrm{L})$. The values of the mean concentrations of heavy metals on soil decreased in the order $\mathrm{Mn}>\mathrm{Zn}>\mathrm{Cu}>\mathrm{Ni}>\mathrm{Cr}>\mathrm{Cd}$. The maximum concentrations of $\mathrm{Mn}, \mathrm{Zn}$ and $\mathrm{Cu}$ give high values, however, it still not exceeding the permissible limit [8]. 
Table 5. Descriptive statistics of heavy metals concentration in the soil samples.

\begin{tabular}{|c|c|c|c|c|}
\hline Variables & Mean & $\begin{array}{c}\text { Standard } \\
\text { Deviation }\end{array}$ & Minimum & Maximum \\
\hline $\mathrm{Cr}$ & 0.089 & 0.100 & 0.003 & 0.235 \\
\hline $\mathrm{Cu}$ & 9.834 & 17.826 & 0.003 & 41.187 \\
\hline $\mathrm{Zn}$ & 18.822 & 19.143 & 0.065 & 45.390 \\
\hline $\mathrm{Ni}$ & 0.889 & 1.0424 & 0.031 & 2.198 \\
\hline $\mathrm{Cd}$ & 0.075 & 0.0638 & 0.010 & 0.174 \\
\hline $\mathrm{Mn}$ & 27.187 & 26.384 & 0.165 & 63.789 \\
\hline
\end{tabular}

Table 6. The guidelines limit of heavy metals in soil [8].

\begin{tabular}{|l|c|c|c|c|c|}
\hline & $\mathbf{C r}$ & $\mathbf{C u}$ & $\mathbf{Z n}$ & $\mathbf{N i}$ & $\mathbf{M n}$ \\
\hline This study & 0.089 & 9.802 & 18.822 & 0.889 & 27.187 \\
\hline World soil average levels & 59.5 & 38.9 & 70 & 29 & 488 \\
\hline
\end{tabular}

\section{Conclusions}

The soil samples were collected from five locations in Perlis includes Jejawi, Kangar, Chuping, Kuala Perlis and Beseri, and undergo the analysis concentration heavy metals in soil. In general, the results showed the concentration of certain elements are higher in the soil samples. From this result, it was found that the level of heavy metals in the soil near to the centralized Chuping industrial areas gives maximum values compared with other location in Perlis. The result showed that the concentration of Mn has the highest value, whereas $\mathrm{Cd}$ has the least and the order observed in this study is $\mathrm{Mn}>\mathrm{Zn}>\mathrm{Cu}>\mathrm{Ni}>\mathrm{Cr}>\mathrm{Cd}$. As a conclusion, increasing anthropogenic activities such as industrial activities and traffic emission have influenced the pollution of heavy metals in the soil.

We are grateful for the university resources provided by Universiti Malaysia Perlis (UniMAP), Malaysia. We also thank to School of Environmental Engineering, UniMAP for providing us with laboratory facilities.

\section{References}

1. Liu, C. Lu, L. Huang, T., Huang, Y., Ding, L., Zhao, W. Environmental research and public health (2016)

2. Rahman, S. H. Applied Sciences 2, 586-601 (2012)

3. Li , Xue, Poon, Chao., Liu, Pin, Applied Geochemistry 16, 1361-1368 (2001).

4. Hezbullah, M., Sultana, S., Chakraborty, S., Patwary, M., Journal of Toxicology and Environmental Health Sciences 8, 1-5 (2016)

5. Wuana, R. A., Okieimen, F. E. ISRN Ecology, 1-20 (2011)

6. Tubaña, B. S., Heckman, J. R., Silicon and plant diseases 7-35 (2015)

7. Mat Ripin, S. N., Hasan, S., Kamal, M. L., Mohd Hashim, N., Malaysian Journal of Analytical Sciences 18, 155-161 (2014)

8. Hasan, S., Kamal, M. L., Mat Ripin, S. N., Mohd Hashim, N., Malaysian Journal of Analytical Sciences 18, 155-161 (2014) 